\title{
FURTHER STUDIES OF THE EFFECTS OF INSULIN ON THE METABOLISM OF VITAMIN $\mathrm{C}^{1}$
}

\author{
By SOL SHERRY AND ELAINE P. RALLI \\ (From the Department of Medicine, New York University College of Medicine, and the Third \\ [New York University] Medical Division, Bellevue Hospital)
}

(Received for publication April 1, 1947)

In studying the metabolism of ascorbic acid in normal and depancreatized dogs it was found that although the animals in both groups synthesized vitamin $C$ and their tissues were saturated with the vitamin, as measured by test doses, the urinary excretion of ascorbic acid for a 24-hour period was significantly and consistently lower in depancreatized dogs receiving insulin than in normal dogs The major factor responsible for this difference in vitamin $C$ excretion between the normal and the diabetic dogs proved to be the daily injections of insulin necessary to control the glycosuria in the depancreatized animal. When the insulin injections were stopped in the diabetic dogs there was a prompt increase in urinary excretion of the vitamin, the total vitamin excretion closely approximating the daily vitamin excretion prior to depancreatization. Furthermore, insulin injections caused a prompt fall in plasma concentration and urinary excretion of ascorbic acid in both normal and diabetic dogs (1). The present re-

1 This research was aided by a grant from the Josiah Macy, Jr., Foundation. port is concerned with an investigation of the mechanisms involved in this reaction.

\section{THE RELATIONSHIP OF THE CHANGE IN PLASMA CONCENTRATION OF ASCORBIC ACID TO THE URINARY EXCRETION OF VITAMIN C}

A constant intravenous infusion containing creatinine was given to a diabetic dog. Urine was collected by means of an indwelling catheter and preserved with sulfuric acid and hydroxyquinoline $(2,3)$. Blood samples were taken at frequent intervals. Regular insulin was injected once the blood level of creatinine and vitamin C were constant. Vitamin $\mathrm{C}$ was determined in the urine by the method of Evelyn $e$ al. (4). Plasma was analyzed for ascorbic acid according to the method of Mindlin and Butler (5).

The results are given in Table I and show that the reabsorption of the vitamin is unaffected in the presence of the falling plasma concentration produced by the administration of insulin. The results indicate that the fall in urinary excretion of vitamin $\mathrm{C}$ following the injection of insulin is secondary to a fall in the plasma concentration of the vitamin and not due to a primary effect on the renal mechanism.

TABLE I

Effect of insulin on the renal mechanism for the reabsorption of ascorbic acid in a diabetic dog

\begin{tabular}{|c|c|c|c|c|c|c|c|c|c|c|}
\hline \multirow[b]{2}{*}{$\begin{array}{l}\text { Dog } \\
\text { No. }\end{array}$} & \multirow[b]{2}{*}{ Status } & \multirow[b]{2}{*}{ Time } & \multirow[b]{2}{*}{$\begin{array}{l}\text { Vit. C } \\
\text { urine }\end{array}$} & \multirow[b]{2}{*}{$\begin{array}{l}\text { Vit. C } \\
\text { plasma }\end{array}$} & \multirow[b]{2}{*}{ Glucose } & \multicolumn{3}{|c|}{ Clearances } & \multirow{2}{*}{\multicolumn{2}{|c|}{$\underset{\text { reabsorption }}{\text { Vitamin C }}$}} \\
\hline & & & & & & Vit $C$ & Crent & $\begin{array}{l}\text { Ratio } \\
\text { vit. C }\end{array}$ & & \\
\hline 211 & Diabetic & $\begin{array}{c}\min . \\
0 \\
11 \\
22 \\
34\end{array}$ & $\begin{array}{c}\text { mgm. \% } \\
\\
2.65 \\
2.47 \\
2.60\end{array}$ & $\begin{array}{l}m g m . \% \\
0.66 \\
0.69 \\
0.72\end{array}$ & $\begin{array}{c}m g m . \% \\
\quad 411 \\
410 \\
408\end{array}$ & $\begin{array}{l}23.48 \\
23.04 \\
20.55\end{array}$ & $\begin{array}{l}56.8 \\
58.6 \\
58.8\end{array}$ & $\begin{array}{l}0.41 \\
0.39 \\
0.33\end{array}$ & $\begin{array}{c}\text { mgm./min. } \\
0.22 \\
0.25 \\
0.28\end{array}$ & $\begin{array}{c}\text { filtrate } \\
\\
0.47 \\
0.42 \\
0.47\end{array}$ \\
\hline \multicolumn{11}{|c|}{ Insulin 20 units I.V. } \\
\hline & & $\begin{array}{l}60 \\
78 \\
92\end{array}$ & $\begin{array}{l}1.20 \\
0.36 \\
0.23\end{array}$ & $\begin{array}{l}0.59 \\
0.49 \\
0.45\end{array}$ & $\begin{array}{l}373 \\
328 \\
262\end{array}$ & $\begin{array}{l}8.36 \\
2.45 \\
1.69\end{array}$ & $\begin{array}{l}55.3 \\
57.9 \\
51.6\end{array}$ & $\begin{array}{l}0.15 \\
0.04 \\
0.03\end{array}$ & $\begin{array}{l}0.28 \\
0.27 \\
0.22\end{array}$ & $\begin{array}{l}0.50 \\
0.47 \\
0.43\end{array}$ \\
\hline
\end{tabular}


II. EFFECT OF DIFFERENT TYPES OF INSULIN AND THE RELATIONSHIP BETWEEN THE EFFECT OF INSULIN AND THE ROUTE OF ADMINISTRATION

In the majority of the experiments regular insulin was used. To rule out the question of whether impurities might be the cause of the response to insulin, crystalline insulin was given in several experiments. This produced a rapid fall in the plasma ascorbic acid concentration similar to that caused by regular insulin.

Experiments in which the insulin was given intravenously, intramuscularly and subcutaneously showed that following the intravenous administration the effects on the plasma level of the vitamin occurred within 15 to 20 minutes, with a maximum effect at about 30 minutes; when injected intramuscularly the effect began in $1 / 2$ to 1 hour with a maximum effect reached in from 2 to 3 hours; and when the insulin was given subcutaneously the effect began after 1 to 2 hours, the maximum effect was reached after 4 to 5 hours, and the duration of the effect was about 6 to 7 hours.

With the insulin doses of 10 to 40 units used in the experiments, there was no correlation between the amounts of insulin and the changes in vitamin $\mathrm{C}$ levels. This is not surprising as it has been observed that the duration of action of insulin on carbohydrate metabolism is not proportional to the size of the dose injected but is a function of the logarithm of the dose (6).

\section{THE MECHANISMS BY WHICH INSULIN MAY CAUSE THE CHANGES OBSERVED IN THE PLASMA LEVEL AND URINARY EXCRE- TION OF VITAMIN C}

The mechanism by which insulin caused a depression in the plasma level and urinary excretion of vitamin $\mathrm{C}$ remained to be investigated. The most likely explanations seemed to be either (a) that insulin might have a direct action on ascorbic acid catalyzing its rate of oxidation or destruction; (b) that in the dog insulin might block the synthesis of ascorbic acid; $(c)$ that the action of insulin on carbohydrate metabolism or other intermediary metabolites might involve ascorbic acid entering into and accelerating the oxidation or utilization of these metabolites in the body and in that way increasing the utilization of vitamin $C$; or $(d)$ that insulin might cause a redistribution of ascorbic acid within the body. A series of experiments were done to study these points.

\section{(a) Action of insulin on ascorbic acid in vitro:}

$4 \mathrm{cc}$. of dog plasma were diluted with an equal amount of distilled water containing 0.8 unit of insulin. This was allowed to stand at room temperature for $1 / 2$ hour before precipitating with $8 \mathrm{cc}$. of $10 \%$ metaphosphoric acid. Another $4 \mathrm{cc}$. of plasma diluted with distilled water but with no insulin added was treated in a similar manner. Determinations of the vitamin $\mathrm{C}$ content were done on both solutions. The solution containing the insulin had $0.49 \mathrm{mgm} . \%$ of vitamin $\mathrm{C}$ and the control solution contained $0.52 \mathrm{mgm}$. \% of the vitamin. Apparently insulin had no effect. In another experiment $30 \mathrm{cc}$. of whole blood was withdrawn from a normal dog and divided into three $10 \mathrm{cc}$. specimens. To the first specimen, $1 \mathrm{cc}$. of $\mathrm{N} /$ saline was added and the whole blood ascorbic acid concentration determined by the method of Butler and Cushman (7). To the second specimen, $1 \mathrm{cc}$. of $\mathrm{N} /$ saline was added and the whole specimen was then incubated at $37^{\circ}$ for 1 hour before determination of the blood ascorbic acid. To the third specimen, 1 .cc. of $\mathrm{N} /$ saline containing 0.6 unit of insulin was added and the specimen was incubated for 1 hour at $37^{\circ} \mathrm{C}$. The concentrations of ascorbic acid of each of the three specimens were $0.6 \mathrm{mgm}$. \%.

The results show that the insulin had no direct effect in vitro on the ascorbic acid in whole blood or plasma.

\section{(b) Action of insulin in blocking the synthesis of ascorbic acid:}

Since the fall in the plasma concentration and urinary excretion of vitamin $C$ following the injection of insulin was always rapid, especially when the insulin was given intravenously, it seemed unlikely that such a rapid effect would be produced simply by blocking the synthesis of the vitamin. Further evidence against this hypothesis of insulin action on vitamin $\mathrm{C}$ metabolism was obtained by experiments done on man, who is incapable of synthesizing the vitamin, and on dogs. Several male diabetic patients served as the human subjects. The normal fasting variations in the plasma concentration of vitamin $\mathrm{C}$ were determined in each diabetic patient at intervals of $1 / 2$ hour for a 3-hour period. After an interval of several days the effect of injecting insulin on the plasma and urine levels of the vitamin was determined. A total of 10 experiments were done on the patients. Without insulin the plasma concentration of vitamin C did not vary by more than $0.10 \mathrm{mgm}$. \% over the 3-hour period.

Following the injection of insulin there was a prompt and significant fall in the plasma concentration of the vitamin. The urinary excretion of the vitamin paralleled the changes in the plasma 
TABLE II

The effect of oral glucose and of insulin on the plasma vitamin $C$ levels of two diabetic patients

\begin{tabular}{|c|c|c|c|c|c|}
\hline Time & $\underset{\text { vitamin C }}{\text { Plasma }}$ & $\begin{array}{l}\text { Blood } \\
\text { sugar }\end{array}$ & Time & $\underset{\text { vitamin C C }}{\text { Plasma }}$ & $\begin{array}{l}\text { Blood } \\
\text { sugar }\end{array}$ \\
\hline $\begin{array}{r}\min . \\
0 \\
33\end{array}$ & $\begin{array}{c}\text { mgm. \% } \\
1.39 \\
1.37\end{array}$ & $\begin{array}{c}\text { mgm. \% } \\
552 \\
544\end{array}$ & $\begin{array}{r}\min . \\
0 \\
33\end{array}$ & $\begin{array}{c}\text { mgm. \% } \\
0.82 \\
0.90\end{array}$ & $\begin{array}{c}\text { mgm. \% } \\
177\end{array}$ \\
\hline \multicolumn{3}{|c|}{ Glucose-100 gm.-orally } & \multicolumn{3}{|c|}{ Glucose-100 gm.-orally } \\
\hline $\begin{array}{r}25 \\
43 \\
62 \\
78 \\
97 \\
118\end{array}$ & $\begin{array}{l}1.41 \\
1.37 \\
1.35 \\
1.32 \\
1.38 \\
1.35\end{array}$ & $\begin{array}{l}624 \\
648 \\
656 \\
704 \\
672 \\
600\end{array}$ & $\begin{array}{r}18 \\
38 \\
56 \\
72 \\
91 \\
108\end{array}$ & $\begin{array}{l}0.86 \\
0.91 \\
0.84 \\
0.83 \\
0.83 \\
0.82\end{array}$ & $\begin{array}{l}308 \\
372 \\
348 \\
320 \\
300 \\
292\end{array}$ \\
\hline Subject & \multicolumn{2}{|c|}{ Sz. } & Subject & \multicolumn{2}{|c|}{ Sp. } \\
\hline Time & $\begin{array}{c}\text { Plasma } \\
\text { vitamin C }\end{array}$ & $\underset{\text { glucose }}{\text { Blood }}$ & Time & $\underset{\text { vitamin C C }}{\text { Plasma }}$ & $\begin{array}{c}\text { Blood } \\
\text { glucose }\end{array}$ \\
\hline $\begin{array}{c}\min . \\
0 \\
29 \\
65\end{array}$ & $\begin{array}{c}\text { mgm. \% } \\
1.24 \\
1.19 \\
1.22\end{array}$ & $\begin{array}{c}\text { mgm. \% } \\
394 \\
378\end{array}$ & $\begin{array}{c}\min . \\
0 \\
37\end{array}$ & $\begin{array}{c}\text { mgm. } \% \\
1.36 \\
1.36\end{array}$ & $\begin{array}{c}\text { mgm. \% } \\
450 \\
424\end{array}$ \\
\hline \multicolumn{3}{|c|}{ Insulin 12 units I.V. } & \multicolumn{3}{|c|}{ Insulin 20 units I.M. } \\
\hline \multirow[t]{3}{*}{$\begin{array}{l}31 \\
62 \\
92\end{array}$} & $\begin{array}{l}1.04 \\
1.10 \\
1.18\end{array}$ & $\begin{array}{l}298 \\
240 \\
220\end{array}$ & $\begin{array}{l}28 \\
60 \\
89\end{array}$ & $\begin{array}{l}1.36 \\
1.12 \\
1.16\end{array}$ & $\begin{array}{l}378 \\
296 \\
275\end{array}$ \\
\hline & & & \multicolumn{3}{|c|}{ Insulin 6 units I.V. } \\
\hline & & & $\begin{array}{l}22 \\
52\end{array}$ & $\begin{array}{l}1.18 \\
1.04\end{array}$ & $\begin{array}{l}186 \\
105\end{array}$ \\
\hline
\end{tabular}

levels. The average fall of plasma ascorbic acid in 10 experiments was $0.22 \pm 0.07 \mathrm{mgm}$. \%. In Table II are given the effects of insulin on the plasma vitamin $\mathrm{C}$ levels of two of the diabetic patients studied. It will be also noted that glucose alone had no effect on plasma vitamin $\mathrm{C}$ levels.

In another experiment a normal female dog, weighing $91 / 4 \mathrm{~kg}$., was studied before and while receiving daily injections of insulin. The study was divided into four periods. In the first period of 7 days, the dog received no insulin; in the second period of 6 days, the animal was given one dose of 5 units of insulin subcutaneously daily; in the third period of 7 days, 10 units daily; and in the fourth period of 6 days, 15 units of insulin. Blood samples were drawn every other day prior to the injection of insulin. Daily 24-hour urinary excretions of ascorbic acid were determined.
The results of this experiment are given in Table III. The 24-hour excretion and fasting plasma concentrations of vitamin $\mathrm{C}$ in this normal dog did not show a decrease in any of the periods, although in acute experiments this same animal responded to injections of insulin with a fall in plasma concentration. If the 24-hour excretion of ascorbic acid is any indication of the synthesis of the vitamin in the dog, then over the 24hour period insulin did not seem to affect the synthesis of the vitamin.

TABLE III

Effect of insulin on the 24-hour urinary excretion of vitamin $C$ in the normal dog

\begin{tabular}{|c|c|c|c|}
\hline No. of days & $\begin{array}{c}\text { Units of } \\
\text { insulin } \\
\text { daily }\end{array}$ & $\begin{array}{c}\text { Average } 24 \mathrm{hr} . \\
\text { excretion } \\
\text { vitamin C }\end{array}$ & $\begin{array}{c}\text { Fasting plasma } \\
\text { vitamin C } \\
\text { average }\end{array}$ \\
\hline $\begin{array}{l}7 \\
6 \\
7 \\
6\end{array}$ & $\begin{array}{c}\text { none } \\
5 \\
10 \\
15\end{array}$ & $\begin{array}{c}\text { mgm. } \\
67 \\
70 \\
72 \\
71\end{array}$ & $\begin{array}{c}\text { mgm. \% } \\
0.44 \\
0.44 \\
0.47 \\
0.48\end{array}$ \\
\hline
\end{tabular}

(c) Possible action of insulin in increasing the utilization of vitamin $C$ :

We have presented some seemingly paradoxical data: i.e., injected insulin in the normal dog causes a rapid but transient fall in plasma concentration and urinary excretion of ascorbic acid; yet the 24hour excretion of ascorbic acid in the same dog seems unaffected by the administration of insulin. This is explained by the finding that after the acute fall of urinary vitamin $C$ following insulin injections there is not only a return to normal but an increased excretion of the vitamin over the expected normal excretion. In another series of experiments the immediate and after effects of insulin on ascorbic acid metabolism were studied. The plasma concentration of ascorbic acid and the urinary excretion were followed hourly for periods of 10 hours. Table IV shows typical experiments. Similar findings were noted in both normal and diabetic dogs and show that, although the immediate effect of insulin is to cause a fall in plasma concentration and urinary excretion of the vitamin, once the immediate effect of the insulin has worn off there is an increased excretion of ascorbic acid for several hours and then a final return again to normal. The changes in the urinary excretion were paralleled by changes in the plasma 
TABLE IV

Experiments showing the immediate and after effects of insulin on the vitamin $C$ levels at hourly intervals Dog No. 227 normal

\begin{tabular}{|c|c|c|c|c|c|c|c|c|c|c|c|}
\hline Hours & $0-1$ & & $1-2$ & $2-3$ & $3-4$ & $4-5$ & $5-6$ & $6-7$ & $7-8$ & $8-9$ & $9-10$ \\
\hline Plasma vitamin $\mathrm{C}$ & 0.42 & Insulin 10 units & 0.31 & 0.22 & 0.28 & 0.35 & 0.45 & 0.49 & 0.45 & & 0.44 \\
\hline $\begin{array}{l}\text { Excretion } \\
\text { vitamin C } \\
\text { mgm./hour } \\
\text { Plasma glucose } \\
\text { mgm. } \%\end{array}$ & $\begin{array}{l}4.1 \\
84\end{array}$ & & $\begin{array}{r}2.2 \\
62\end{array}$ & $\begin{array}{r}1.3 \\
28\end{array}$ & $\begin{array}{r}2.0 \\
33\end{array}$ & 2.8 & $\begin{array}{r}5.9 \\
36\end{array}$ & $\begin{array}{l}13.4 \\
61\end{array}$ & $\begin{array}{l}9.6 \\
84\end{array}$ & $\begin{array}{c}6.4 \\
95 .\end{array}$ & $\begin{array}{r}4.5 \\
97\end{array}$ \\
\hline
\end{tabular}

Dog No. 241 diabetic

\begin{tabular}{c|c|c|c|c|c|c|c|c|c|c|c}
\hline Hours & $0-1$ & & $1-2$ & $2-3$ & $3-4$ & $4-5$ & $5-6$ & $6-7$ & $7-8$ & $8-9$ & $9-10$ \\
\hline $\begin{array}{c}\text { Plasma vitamin C } \\
\begin{array}{c}\text { mgm. \% } \\
\text { Plasma glucose } \\
\text { mgm. \% }\end{array}\end{array}$ & 0.57 & $\begin{array}{l}\text { Insulin 20 units } \\
\text { subcutaneously }\end{array}$ & 0.45 & 0.35 & 0.35 & 0.44 & 0.60 & 0.71 & 0.74 & 0.66 & 0.60 \\
\hline
\end{tabular}

levels of the vitamin. The latter were not as striking as the urinary changes but occurred consistently in all the animals studied. Although this explains the findings in the normal dogs, it does not explain why the diabetic dog over 24-hour periods excretes less vitamin $\mathrm{C}$ than does the normal dog.

In order to test the hypothesis of increased utilization after injections of insulin, a series of experiments were done on rats, humans and guinea pigs. Five normal albino rats weighing 250 to 300 gms. were placed in individual metabolism cages suspended on large funnels containing a fine mesh filter. They were fed a Purina chow diet (which is devoid of ascorbic acid) and allowed water ad lib. 24-hour urines were collected into dark bottles containing sulfuric acid and hydroxyquinoline. The urines were analyzed for their vitamin $\mathrm{C}$ content. Each animal acted as its own control. The daily excretion of ascorbic acid was observed on diet alone for 7 days; then for the next 8 days insulin was injected once daily starting.with 0.2 unit subcutaneously and increasing the dose by 0.1 unit each day, so that on the 8th day each animal received 0.9 unit of insulin. The animals were then observed for 7 days longer under conditions similar to the control period.

The results of this experiment are given in Table V. They show that insulin in the doses used had no effect on the 24-hour urinary excretion of ascorbic acid. It is concluded that in the normal rat, insulin does not increase the utilization of ascorbic acid.

Experiments were also done on human subjects. As previously stated man is incapable of synthesizing ascorbic acid and as the fecal excre- tion of the vitamin is fairly constant and minimal (8) the 24-hour urinary excretion of the vitamin affords a measure of the difference between the daily intake and the metabolism or storage of vitamin C (9). The question of storage can be controlled by saturating an individual with the vitamin and maintaining him on a large dose daily, under which conditions the difference between

TABLE V

Effect of insulin on the daily urinary excretion of vitamin $C$ in albino rats on the Purina chow diet

\begin{tabular}{|c|c|c|c|c|c|}
\hline Rat No. & Age & Wt. & $\begin{array}{c}\text { No. of } \\
\text { days }\end{array}$ & $\begin{array}{c}\text { Average } \\
\text { 24-hr. } \\
\text { urinary } \\
\text { excretion } \\
\text { vitamin C }\end{array}$ & $\underset{\text { units }}{\text { Insulin* }}$ \\
\hline 1 & $\begin{array}{l}\text { days } \\
112\end{array}$ & $\begin{array}{l}\text { gm. } \\
277 \\
288 \\
299\end{array}$ & $\begin{array}{l}7 \\
8 \\
8\end{array}$ & $\begin{array}{c}m g m . \\
1.2 \\
1.3 \\
1.4\end{array}$ & $\begin{array}{c}\text { none } \\
0.2-0.9 \\
\text { none }\end{array}$ \\
\hline 2 & 112 & $\begin{array}{l}273 \\
273 \\
267\end{array}$ & $\begin{array}{l}7 \\
8 \\
7\end{array}$ & $\begin{array}{l}4.1 \\
2.1 \\
2.4\end{array}$ & $\begin{array}{c}\text { none } \\
0.2-0.9 \\
\text { none }\end{array}$ \\
\hline 3 & 112 & $\begin{array}{l}286 \\
292 \\
293\end{array}$ & $\begin{array}{l}7 \\
8 \\
7\end{array}$ & $\begin{array}{l}5.0 \\
4.6 \\
5.6\end{array}$ & $\begin{array}{c}\text { none } \\
0.2-0.9 \\
\text { none }\end{array}$ \\
\hline 4 & 112 & $\begin{array}{l}260 \\
270 \\
283\end{array}$ & $\begin{array}{l}7 \\
8 \\
7\end{array}$ & $\begin{array}{l}2.3 \\
2.2 \\
2.5\end{array}$ & $\begin{array}{c}\text { none } \\
0.2-0.9 \\
\text { none }\end{array}$ \\
\hline 5 & 112 & $\begin{array}{l}262 \\
285 \\
285\end{array}$ & $\begin{array}{l}7 \\
8 \\
7\end{array}$ & $\begin{array}{l}3.4 \\
2.0 \\
2.2\end{array}$ & $\begin{array}{c}\text { none } \\
0.2-0.9 \\
\text { none }\end{array}$ \\
\hline
\end{tabular}

* Rats were started on $\mathbf{0 . 2}$ unit of insulin daily and this was increased 0.1 unit daily. 
TABLE VI

Effect of insulin on the 24-hour urinary excretion of vitamin $C$ in a normal adult male on $200 \mathrm{mgm}$. of vitamin $C$ daily

\begin{tabular}{|c|c|c|c|c|}
\hline $\begin{array}{l}\text { No. of } \\
\text { days }\end{array}$ & $\begin{array}{l}\text { Units of } \\
\text { insulin daily }\end{array}$ & $\begin{array}{l}\text { Average 24- } \\
\text { excretion of }\end{array}$ & $\begin{array}{l}\text { urinary } \\
\text { itamin C }\end{array}$ & $\begin{array}{c}\text { Average } \\
\text { fasting } \\
\text { plasma }\end{array}$ \\
\hline 9 & none & $\underset{70}{m g m .} \pm$ & $\begin{array}{l}\text { s.d. } \\
11\end{array}$ & $\begin{array}{c}m g m . \% \\
1.21\end{array}$ \\
\hline 14 & $\begin{array}{l}10 \text { u. }-1 \text { day } \\
15 \text { u. }-1 \text { day } \\
20 \text { u. }-1 \text { day } \\
30 \text { u. }-3 \text { days } \\
35 \text { u. }-2 \text { days } \\
40 \text { u. }-2 \text { days } \\
45 \text { u. }-4 \text { days }\end{array}$ & $84 \pm$ & 18 & 1.12 \\
\hline 4 & none & 83 & & 1.18 \\
\hline
\end{tabular}

the daily intake and excretion of vitamin $\mathrm{C}$ is a measure of the utilization.

A normal adult male, who in previous experiments had shown a fall in the plasma level of vitamin $C$ following injections of insulin, was maintained on a diet free of vitamin C. At the start of the experiment he was given large doses of crystalline vitamin $\mathrm{C}$ orally $(7,100$ $\mathrm{mgm}$. in an 8-day period) in order to assure saturation of his tissues, and then was maintained on a daily dose of $200 \mathrm{mgm}$. Twenty-four hour urine samples were collected for determination of vitamin $\mathrm{C}$ and the plasma levels were done three times weekly. After a suitable control period insulin was injected subcutaneously daily beginning with 10 units and increasing to 45 units daily. The observations were continued for a short period following the withdrawal of insulin.

The results of this experiment are given in Table VI. The injections of insulin did not significantly affect the 24-hour urinary excretion of ascorbic acid, which would indicate that insulin does not increase the rate of utilization of ascorbic acid in man. This fact was further demonstrated in an experiment on guinea pigs, the results of which are given in Table VII. The onset of the signs of scurvy and the severity of the lesions at autopsy were not affected when insulin was given daily to the animals on the vitamin C-free diet. The evidence cited in experiments on dogs, rats, humans and guinea pigs does not suggest that insulin produces the acute effects on vitamin C levels through an increased utilization of the vitamin resulting in its loss from the body.

\section{(d) Does insulin cause a redistribution of vitamin $C$ in the body tissues?}

None of the theories so far discussed adequately explains the acute effects of insulin on the plasma

TABLE VII

Effect of the daily injection of insulin in guinea pigs on a scorbutic diet*

\begin{tabular}{|c|c|c|c|c|c|c|c|c|c|c|c|c|c|}
\hline \multirow{3}{*}{$\begin{array}{l}\text { Pig } \\
\text { No. }\end{array}$} & \multirow{3}{*}{$\begin{array}{l}\text { Units of } \\
\text { insulin } \\
\text { daily }\end{array}$} & \multicolumn{2}{|c|}{$\begin{array}{c}\text { Weight } \\
\text { gms. }\end{array}$} & \multirow{3}{*}{$\begin{array}{l}\text { Day of } \\
\text { onset of } \\
\text { severe } \\
\text { scurvy }\end{array}$} & \multirow{3}{*}{$\begin{array}{l}\text { Day of } \\
\text { death }\end{array}$} & \multicolumn{8}{|c|}{ Grading of autopsy findings } \\
\hline & & \multirow{2}{*}{ Onset } & \multirow{2}{*}{ Final } & & & \multicolumn{4}{|c|}{ Bony system changes } & \multicolumn{4}{|c|}{ Hemorrhages } \\
\hline & & & & & & $\begin{array}{l}\text { Long } \\
\text { bones }\end{array}$ & Teeth & Ribs & Joints & Ribs & Intest. & Joints & Muscles \\
\hline $\begin{array}{l}1 \\
2 \\
3 \\
8\end{array}$ & $\begin{array}{l}\text { none } \\
\text { none } \\
\text { none } \\
\text { none }\end{array}$ & $\begin{array}{l}310 \\
290 \\
268 \\
330\end{array}$ & $\begin{array}{l}220 \\
303 \\
330 \\
253\end{array}$ & $\begin{array}{l}14 \\
14 \\
13 \\
22\end{array}$ & $\begin{array}{l}30 \ddagger \\
23 \\
28 \\
30 \ddagger\end{array}$ & $\begin{array}{l}4+ \\
1+ \\
2+ \\
4+\end{array}$ & $\begin{array}{l}3+ \\
1+ \\
2+ \\
1+\end{array}$ & $\begin{array}{l}2+ \\
2+ \\
2+ \\
4+\end{array}$ & $\begin{array}{l}3+ \\
2+ \\
2+ \\
3+\end{array}$ & $\begin{array}{l}1+ \\
2+ \\
3+ \\
3+\end{array}$ & $\begin{array}{l}2+ \\
4+ \\
3+ \\
4+\end{array}$ & $\begin{array}{l}2+ \\
3+ \\
3+ \\
4+\end{array}$ & $\begin{array}{l}4+ \\
3+ \\
4+ \\
4+\end{array}$ \\
\hline $\begin{array}{l}4 t \\
5 t \\
6 t \\
7 t \\
9 t\end{array}$ & $\begin{array}{l}0.6 \\
0.6 \\
0.6 \\
0.6 \\
0.6\end{array}$ & $\begin{array}{l}281 \\
288 \\
350 \\
282 \\
326\end{array}$ & $\begin{array}{l}194 \\
250 \\
331 \\
209 \\
325\end{array}$ & $\begin{array}{l}16 \\
15 \\
15 \\
15 \\
18\end{array}$ & $\begin{array}{l}30 \ddagger \\
26 \\
30 \ddagger \\
26 \\
30 \ddagger\end{array}$ & $\begin{array}{l}2+ \\
2+ \\
2+ \\
3+ \\
4+\end{array}$ & $\begin{array}{l}4+ \\
4+ \\
4+ \\
4+ \\
1+\end{array}$ & $\begin{array}{l}2+ \\
2+ \\
4+ \\
2+ \\
2+\end{array}$ & $\begin{array}{l}3+ \\
3+ \\
2+ \\
1+ \\
3+\end{array}$ & $\begin{array}{l}2+ \\
1+ \\
2+ \\
2+ \\
1+\end{array}$ & $\begin{array}{l}1+ \\
1+ \\
1+ \\
4+ \\
1+\end{array}$ & $\begin{array}{l}3+ \\
3+ \\
4+ \\
2+ \\
3+\end{array}$ & $\begin{array}{c}3+ \\
4+ \\
4+ \\
2+ \\
4+\end{array}$ \\
\hline
\end{tabular}

* The diet consisted of rolled oats $39 \%$, bran $20 \%$, skimmed milk powder (heated to $110^{\circ} \mathrm{C}$ ) $30 \%$, butter fat $10 \%$ and $\mathrm{NaCl} 1 \%$. Each pig received 1 drop of Cod Liver Oil daily.

$\dagger$ The pigs on insulin were started on 0.2 units daily. This was increased 0.2 units daily to a dose that caused symptoms of shock and the pig was then carried on $2 / 3$ of that amount.

$\ddagger$ These pigs were sacrificed and the vitamin $C$ content of the plasma was determined. In every instance it was zero.

8 The findings at autopsy were graded as follows: $1+$ (mild changes), $2+$ (moderate), $3+$ (severe), $4+$ (very severe). For the bony system, the findings of looseness of the teeth, fragility of bones, spontaneous fractures of the long bones, enlargement and hemorrhages of the joints and ribs, and separation of the epiphyses were graded. For hemorrhages, the number and extent of hemorrhages were graded. 
level and urinary excretion of vitamin C. It seemed to us that a satisfactory explanation of the facts might be that insulin causes a redistribution of ascorbic acid in the body: i.e., that the vitamin passes from the plasma into the tissues or tissue fluids and that, as the effect of insulin wears off, the vitamin again returns to the plasma. The proof of such an hypothesis would depend on demonstrating that coincident with the fall in plasma concentration of vitamin $\mathrm{C}$ there occurred a rise in concentration in the tissues or in some specific tissue and that the changes in concentration would quantitatively balance one another.

Quantitatively accurate determinations of the vitamin $\mathrm{C}$ content of muscles and organs under the conditions necessary in these experiments were not practical. However, the methods for determining the vitamin $C$ content of whole blood, red blood cells and the white blood cellplatelet layer of the blood as well as the plasma were satisfactory and therefore the determination of these components of the blood were done before and after the administration of insulin. Control blood samples were taken and, following the injection of insulin, samples were collected at suitable intervals depending on the mode of administration of the insulin. Eleven experiments were done and the results are shown graphically in Figure 1 and the details are given in Table VIII. The methods

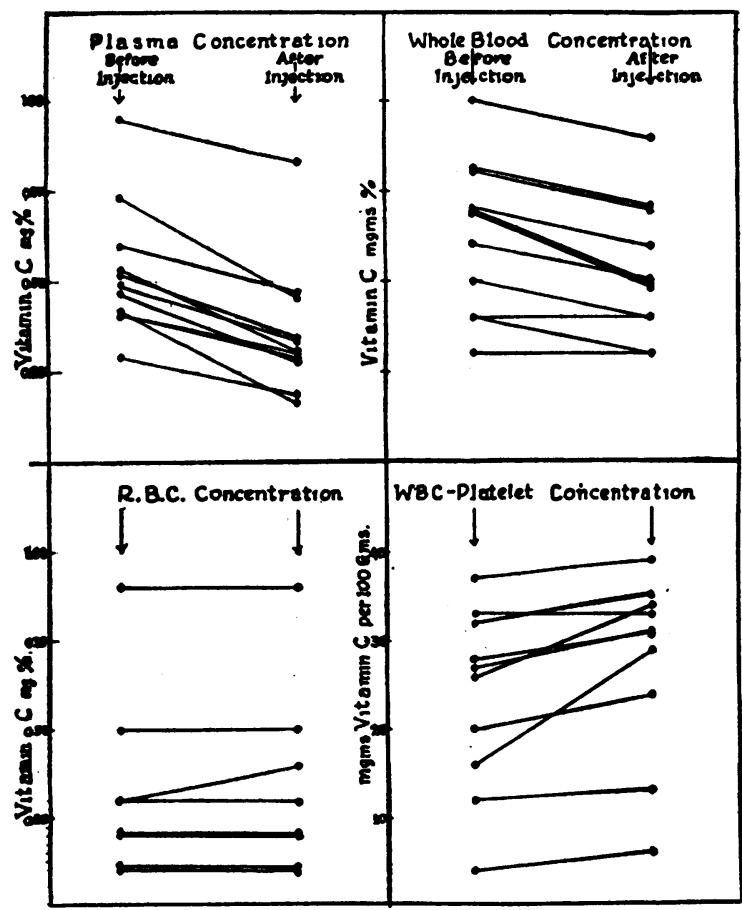

Fig. 1. Concentration of Vitamin C in Blood Constituents Before and After Insulin of determining the vitamin $\mathrm{C}$ concentration in the various blood fractions were those described by Butler and Cushman (7). In 6 experiments hematocrit determinations were made and the calculated and observed values for the whole blood ascorbic acid were found to agree closely.

In all of the 11 experiments there was a fall in plasma concentration of ascorbic acid after the injection of insulin. In 10 of the 11 experiments the fall can be considered significant. In one experiment the fall was within the extremes of normal variation. Of 8 experiments in which the R.B.C. concentration of ascorbic acid was determined ( 7 directly and one by calculation), there was no change in R.B.C. concentration of the vitamin in 7 experiments. In one experiment there was a slight rise in concentration of vitamin $\mathrm{C}$ following injection of insulin. In 9 of 10 experiments there was a rise in the concentration of ascorbic acid of the buffy layer (W.B.C.-platelet) after insulin; 4 of the increases were definitely significant (over $3 \mathrm{mgm} . \%$ ), while 5 were not greater than the range of error of the method. The average determined increase after insulin in the buffy layer concentration for the 10 experiments was $4 \mathrm{mgm} . / 100$ gms. leukocytes. In 6 experiments calculation of the W.B.C.-platelet layer concentration of ascorbic acid from the determined hematocrit, whole blood, plasma and red blood cell concentrations showed an average rise of $5 \mathrm{mgm} . / 100 \mathrm{gms}$. leukocytes following insulin administration. We think the changes are significant. There was a slight fall in whole blood concentration of vitamin $C$ in 9 experiments. In the other two no change was noted. The results suggest that after the injection of insulin there is a fall in the plasma and the whole blood concentration of ascorbic acid; no change in the red blood cell ascorbic acid content; and a rise in the vitamin C concentration of the W.B.C.-platelet layer.

\section{DISCUSSION}

The results of the series of experiments reported here and previously (1) show that following the injection of insulin into a normal or diabetic dog or a human normal or diabetic subject, there results $\dot{a}$ fall in plasma concentration and an attendant drop in the urinary excretion of vitamin $C$; that this effect wears off after a variable period of time and is followed by a rise in plasma concen- 
TABLE VIII

The effect of insulin on the concentration of vitamin $C$ in the various elements of the blood

\begin{tabular}{|c|c|c|c|c|c|c|c|c|}
\hline $\begin{array}{l}\text { Experiment } \\
\text { No. }\end{array}$ & Animal & $\begin{array}{l}\text { Units of } \\
\text { insulin } \\
\text { given }\end{array}$ & $\begin{array}{c}\text { Time after } \\
\text { insulin }\end{array}$ & $\underset{\text { plasma }}{\text { Vitamin }} \mathbf{C}$ & $\begin{array}{l}\text { Vitamin C } \\
\text { red blood } \\
\text { cells }\end{array}$ & $\begin{array}{c}\text { Vitamin C } \\
\text { W.B.C.-E } \\
\text { platelet layer }\end{array}$ & $\begin{array}{c}\text { Vitamin } \\
\text { whole } \\
\text { blood }\end{array}$ & Blood sugar \\
\hline 1 & Dog 232 & $\begin{array}{l}20 \text { I.V. } \\
15 \text { I.V. }\end{array}$ & $\begin{array}{l}\text { Fasting } \\
1 \text { hour }\end{array}$ & $\begin{array}{l}\text { mgm. \% } \\
0.41 \\
0.30\end{array}$ & $\begin{array}{c}\text { mgm. \% } \\
0.1 \\
0.1\end{array}$ & $\begin{array}{c}m g m . / 100 \mathrm{gm} . \\
27 \\
31\end{array}$ & $\begin{array}{l}\text { mgm. \% } \\
0.6 \\
0.5\end{array}$ & mgm. \% \\
\hline 2 & $\begin{array}{l}\text { Human dia- } \\
\text { betic patient }\end{array}$ & 35 I.V. & $\begin{array}{l}\text { Fassting } \\
45 \text { min. }\end{array}$ & $\begin{array}{l}0.95 \\
0.83\end{array}$ & $\begin{array}{l}0.9 \\
0.9\end{array}$ & $\begin{array}{l}32 \\
35\end{array}$ & $\begin{array}{l}1.0 \\
0.9\end{array}$ & $\begin{array}{l}303 \\
123\end{array}$ \\
\hline 3 & Dog 234 & $\begin{array}{l}20 \\
\text { Subcut. }\end{array}$ & $\begin{array}{l}\text { Fasting } \\
2 \text { hours }\end{array}$ & $\begin{array}{l}0.49 \\
0.33\end{array}$ & & $\begin{array}{l}26 \\
34\end{array}$ & $\begin{array}{l}0.8 \\
0.7\end{array}$ & \\
\hline 4 & Dog 236 & $\begin{array}{l}20 \\
\text { Subcut. }\end{array}$ & $\begin{array}{l}\text { Fasting } \\
2 \text { hours }\end{array}$ & $\begin{array}{l}0.42 \\
0.17 \ddagger\end{array}$ & & $\begin{array}{l}12 \\
13\end{array}$ & $\begin{array}{l}0.4 \\
0.3\end{array}$ & \\
\hline 5 & Dog 234 & $\begin{array}{l}20 \\
\text { Subcut. }\end{array}$ & $\begin{array}{l}\text { Fasting } \\
2 \text { hours }\end{array}$ & $\begin{array}{l}0.60 \\
0.47\end{array}$ & & & $\begin{array}{l}0.7 \\
0.5\end{array}$ & $\begin{array}{l}\text { Dog in } \\
\text { Shock }\end{array}$ \\
\hline 6 & Dog 234 & $\begin{array}{l}20 \text { I.V. } \dagger \\
20 \text { I.M. } \dagger\end{array}$ & $\begin{array}{l}\text { Fasting } \\
45 \text { min. }\end{array}$ & $\begin{array}{l}0.53 \\
0.31\end{array}$ & $\begin{array}{l}0.2^{*} \\
0.2^{*}\end{array}$ & $\begin{array}{l}33 \\
33\end{array}$ & $\begin{array}{l}0.5 \\
0.4\end{array}$ & $\begin{array}{l}98 \\
40\end{array}$ \\
\hline 7 & Dog 234 & $\begin{array}{l}20 \text { I.V. } \\
30 \text { I.M. }\end{array}$ & $\begin{array}{l}\text { Fasting } \\
1 \text { hour }\end{array}$ & $\begin{array}{l}0.52 \\
0.34\end{array}$ & $\begin{array}{l}0.3 \\
0.4\end{array}$ & $\begin{array}{l}37 \\
39\end{array}$ & $\begin{array}{l}0.7 \\
0.6\end{array}$ & \\
\hline 8 & Dog 234 & $\begin{array}{l}25 \text { I.V. } \\
25 \text { I.M. }\end{array}$ & $\begin{array}{l}\text { Fasting } \\
1 \text { hour }\end{array}$ & $\begin{array}{l}0.73 \\
0.46\end{array}$ & $\begin{array}{l}0.3 \\
0.3\end{array}$ & $\begin{array}{l}16 \\
29\end{array}$ & $\begin{array}{l}0.8 \\
0.7\end{array}$ & \\
\hline 9 & Dog $227 \S$ & $\begin{array}{l}15 \text { I.V. } \\
20 \text { I.M. }\end{array}$ & $\begin{array}{l}\text { Fasting } \\
50 \text { min. }\end{array}$ & $\begin{array}{l}0.29 \\
0.19\end{array}$ & $\begin{array}{l}0.1 \\
0.1\end{array}$ & $\begin{array}{l}4 \\
6\end{array}$ & $\begin{array}{l}0.3 \\
0.3\end{array}$ & \\
\hline 10 & Dog 231 & $\begin{array}{l}20 \text { I.V. } \\
20 \text { I.M. }\end{array}$ & $\begin{array}{l}\text { Fasting } \\
50 \text { min. }\end{array}$ & $\begin{array}{l}0.41 \\
0.29\end{array}$ & $\begin{array}{l}0.2 \\
0.2\end{array}$ & $\begin{array}{l}20 \\
24\end{array}$ & $\begin{array}{l}0.4 \\
0.4\end{array}$ & \\
\hline 11 & Dog 234 & $\begin{array}{l}20 \text { I.V. } \\
10 \text { Sub. }\end{array}$ & $\begin{array}{l}\text { Fasting } \\
45 \text { min. }\end{array}$ & $\begin{array}{l}0.47 \\
0.28\end{array}$ & $\begin{array}{l}0.5 \\
0.5\end{array}$ & $\begin{array}{l}28 \\
31\end{array}$ & $\begin{array}{l}0.7 \\
0.5\end{array}$ & $\begin{array}{l}89 \\
33\end{array}$ \\
\hline
\end{tabular}

* By calculation from hematocrit.

† Crystalline insulin.
† Slight hemolysis present.

$\$$ Dog had lost considerable weight and was severely diabetic. tration and an increased excretion of ascorbic acid, and finally by a return to the normal levels. The results indicate that there is no loss of ascorbic acid from the body and suggest that vitamin $C$ may be redistributed within the tissues coincident with some metabolic action of insulin. One would be tempted to relate this redistribution to changes in carbohydrate metabolism; but no evidence to this effect was found in the experiments done. Associated with the effect of insulin was a transfer of ascorbic acid from the plasma to the W.B.C.platelet layer of the blood. The ability of vitamin C to shift rapidly from the plasma to the W.B.C. layer has been demonstrated both in vitro by Heinemann (10) and in vivo by ourselves in experiments on leukemic patients (11). The in vitro transfer of vitamin $C$ from the W.B.C. layer to plasma is reported to be a slow process (12).
There is much indirect evidence that the W.B.C.platelet layer concentration of ascorbic acid is an index of tissue concentration $(13,14)$. Since we noted a small increase in the buffy layer concentration after insulin injections, and as this by calculation only accounted for a small per cent of the temporary plasma loss of ascorbic acid and for none of the whole blood loss, it is suggested that vitamin $C$ passes from the plasma and extracellular compartment not only into the W.B.C.-platelet layer but into the tissues as well and that it is eventually returned to the plasma. Our experiments indicate that the action does not seem to involve an actual utilization of ascorbic acid, but rather suggest that it may have some catalytic function. Haid (15) has noted a noticeable decrease in ascorbic acid content of the blood after large doses of insulin. He suggests that vitamin $\mathrm{C}$ wanders from the blood stream into the tissues, 
particularly the liver, and also suggests that there exists a close relationship between vitamin $C$ and carbohydrate metabolism. Göbell and Krause (16) found that the administration of insulin and also adrenalin and nicotinamide lowered the content of reduced and dehydroascorbic acid in the blood. They suggested, as we have, that the increased metabolism in tissues temporarily deflected ascorbic acid from blood to tissues and that, after the stimulus to metabolism was over, vitamin $C$ returned to the blood having fulfilled its role as a catalyst. If ascorbic acid does have some catalytic function in intermediary carbohydrate metabolism then one might expect to find a decreased carbohydrate tolerance in scorbutic subjects and improvement in tolerance following vitamin $\mathrm{C}$ therapy. This has been reported in the scorbutic guinea pig by Sigal and King (17). The literature on the relationship of ascorbic acid to carbohydrate metabolism has been confusing due to the fact that most of the observations have been on animals capable of synthesizing ascorbic acid (dogs, rabbits and rats) whose tissues are probably saturated with the vitamin, or on humans in whom the state of vitamin $C$ nutrition has not been taken into account. (Studies of carbohydrate metabolism in human scurvy and severe ascorbic acid deficiency states, before and after vitamin $\mathrm{C}$ therapy, would be interesting.)

Insulin has been repeatedly demonstrated to cause a fall in plasma inorganic phosphate (18), potassium (19) and uric acid (20). It may well be that factors governing the above changes may also play a part in the changes in ascorbic acid noted.

\section{SUMMARY}

The mechanism by which insulin causes a prompt fall in plasma and urinary vitamin $C$ levels was investigated. It was found that insulin caused these changes regardless of whether it was injected subcutaneously, intravenously or intramuscularly. There were, however, significant differences in both the onset and duration of the effects of insulin on both the plasma levels and excretion of vitamin $\mathrm{C}$ depending on the route of administration of the insulin. The insulin effects in each instance were transient and were followed by a period in which the plasma level and the uri- nary excretion were elevated. This was followed by a return of the vitamin $\mathrm{C}$ levels to normal.

In all species studied-man, dog and rats-these changes in vitamin $\mathrm{C}$ occurred in the plasma and urine following injections of insulin.

Studies in dogs, rats, guinea pigs, and humans, and determinations of the vitamin $C$ content of blood constituents directed toward establishing the mechanism of the action of insulin on vitamin C metabolism showed: $(a)$ that insulin had no effect in vitro; and (b) that insulin did not affect the synthesis of ascorbic acid. It appears that insulin causes a fall in plasma and whole blood ascorbic acid content ; exerts no effect on R.B.C. ascorbic acid content; and is associated with a rise in the W.B.C.-platelet layer concentration of vitamin $C$.

It is suggested that insulin in its action or actions causes a transient transfer of ascorbic acid from the plasma and extracellular fluid into the tissues, possibly for some catalytic function of ascorbic acid.

\section{BIBLIOGRAPHY}

1. Ralli, E. P., and Sherry, S., Effect of insulin on plasma level and excretion of vitamin C. Proc. Soc. Exper. Biol. \& Med., 1940, 43, 669.

2. Barron, E. S. G., Brumm, H. J., and Dick, G. F., Ascorbic acid in the blood and urine after intravenous injection of sodium ascorbate; clinical test for determining vitamin C deficiency. J. Lab. \& Clin. Med., 1938, 23, 1226.

3. Sendroy, J., and Miller, B. F., Renal function as a factor in the urinary excretion of ascorbic acid. J. Clin. Invest., 1939, 18, 135.

4. Evelyn, K. A., Malloy, H. T., and Rosen, C., The determination of ascorbic acid in urine with the photoelectric colorimeter. J. Biol. Chem., 1938, 126, 645.

5. Mindlin, R. L., and Butler, A. M., The determination of ascorbic acid in plasma; a macromethod and micromethod. J. Biol. Chem., 1938, 122, 673.

6. Best, C. H., and Taylor, N. B., Physiological Basis of Medical Practice. The Williams and Wilkins Co., Baltimore, 1945, Ed. 4, p. 581.

7. Butler, A. M., and Cushman, M., Distribution of ascorbic acid in the blood and its nutritional significance. J. Clin. Invest., 1940, 19, 459.

8. Chinn, H., and Farmer, C. J., Determination of ascorbic acid in feces. Its excretion in health and disease. Proc. Soc. Exper. Biol. \& Med., 1939, 41, 561.

9. Ralli, E. P., Friedman, G. J., and Sherry, S., The vitamin $C$ requirement of man. Estimated after 
prolonged studies of the plasma concentration and daily excretion of vitamin $C$ in 3 adults on controlled diets. J. Clin. Invest., 1939, 18, 705.

10. Heinemann, M., Influences of erythrocytes and of leukocytes on stability and transfer of ascorbic acid in human blood. J. Clin. Invest., 1941, 20, 467.

11. Ralli, E. P.,, and Sherry, S., Adult scurvy and the metabolism of vitamin C. Medicine, 1941, 20, 251.

12. Heinemann, M., Distribution of ascorbic acid between cells and serum of human blood. J. Clin. Invest., 1941, 20, 39.

13. Crandon, J. H., Lund, C. C., and Dill, D. B., Experimental human scurvy. New England J. of Med., 1940, 233, 353.

14. Lowry, O. H., Bessey, O. A., Brock, M. J., and Lopez, J. A., The interrelationship of dietary, serum, white blood cell, and total body ascorbic acid. J. Biol. Chem., 1946, 166, 111.
15. Haid, $\mathrm{H}$., Behavior of vitamin $\mathrm{C}$ content of blood during insulin shock. Ztschr. f. klin. Med., 1941, 139, 435 (abst. J. A. M. A., 1942, 120, 653).

16. Göbell, O., and Krause, B., Einfluss Einiger Wirkstoffe auf den Gehalt des Blutes an Ascorbinsäure. Klin. Wchnschr., 1941, 20, 342 (quoted from Nutrition Abstr. \& Rev., 1942, 12, 407).

17. Sigal, A., and King, C. G., The relationship of vita$\min \mathrm{C}$ to glucose tolerance in the guinea pig. $\mathrm{J}$. Biol. Chem., 1936, 116, 489.

18. Soskin, S., and Levine, R., Carbohydrate Metabolism: Correlation of Physiological, Biochemical, and Clinical Aspects. U. of Chicago Press, Chicago, 1946, p. $172 \mathrm{ff}$.

19. Fenn, W. O., The role of potassium in physiological processes. Physiol. Rev., 1940, 20, 377.

20. Rosenberg, E. F., Effect of insulin on the concentration of uric acid in the blood. J. Clin. Invest., 1938, 17, 233. 